\title{
Prescribility of generic microemulsion Cyclosporine A in heart transplant patients
}

Prescritibilidade de Ciclosporina A genérica microemulsão em transplantados cardíacos

Ricardo MANRIQUE ${ }^{1}$, Hélio M. MAGALHÃES ${ }^{1}$, Jarbas DINKHUYSEN ${ }^{1}$, Edileide CORREIA ${ }^{1}$, Hui Tsu LINWANG $^{1}$, Marcos VASCONCELLOS ${ }^{1}$, Eliete CARVALHO ${ }^{1}$, Juan A. C. MEJIA², João D de SOUZA NETO²

RBCCV 44205-631

Abstract

Object: This paper aims to define the prescribility (therapeutic efficacy and bio-safety) of generic microemulsion Cyclosporin (Sigmasporin Microral ${ }^{\circledR}$ ).

Method: Casuistic: Twenty heart transplantation patients, 13 males and 7 females, with a mean age of 49.6 years, began immunosuppression treatment with generic microemulsion cyclosporin (Sigmasporin Microral $\left.{ }^{\circledR}\right)$. They underwent clinical and laboratory evaluation during a minimum of three months. Procedures included clinic evaluation with electro and echocardiogram, endomyocardial biopsy, routine biochemical and hematological tests.

Results: The mean follow-up was 10 months with a maximum of 16 months. A total of 151 endomyocardial biopsies were evaluated: $31.7 \%$ were degree $0,43.7 \%$ 1a and $23.1 \% 1 \mathrm{~b}$. We had only one case of acute clinical rejection confirmed by biopsy as IIIa, and one patient with mediastinitis, both of whom had a good evolution. The mean cyclosporin blood level was $303 \mathrm{Ng} / \mathrm{mL}$. All other parameters also showed a good evolution.

Conclusion: Generic microemulsion cyclosporin (Sigmasporin Microral ${ }^{\circledR}$ ) shows therapeutic efficacy and an excellent bio-safety profile. Its Prescribility is confirmed.

Descriptors: Cyclosporine, pharmacokinetics. Cyclosporine, toxicity. Cyclosporine, therapeutic use. Immunossupressives. Heart transplantation.

\begin{abstract}
Resumo
Objetivo: Determinar a prescritibilidade (eficácia terapêutica e biosegurança) da Ciclosporina microemulsão genérica.

Método: Casuística: 20 transplantados cardíacos, sendo 13 homens e sete mulheres, com idade média de 49,62 anos, iniciaram o tratamento tríplice imunossupressor, com Ciclosporina microemulsão genérica ou Sigmasporin Microral ${ }^{\circledR}$. A condição para inclusão era ter um seguimento mínimo de três meses. Procedimentos: avaliação clínica, biópsias endomiocárdicas, dosagem de ciclosporina, exames de rotina de bioquímica e hematologia.

Resultados: O período de observação médio foi de 10 meses e máximo de 16 meses. Foram avaliadas 151 biópsias, sendo $31,7 \%$ - grau $0,43,7 \%$ - Ia e 23,1\% - Ib. Obtivemos uma rejeição clínica confirmada com biópsia III a e uma mediastinite, ambas com boa evolução. A ciclosporinemia média foi de $\mathbf{3 0 3}$ $\mathrm{ng} / \mathrm{ml}$. A evolução destes pacientes transcorreu sem outros problemas.

Conclusão: A Ciclosporina microemulsão genérica demonstrou excelente eficácia terapêutica e biosegurança, sendo portanto considerada prescritível.
\end{abstract}

Descritores: Ciclosporina, farmacologia. Ciclosporina, toxicidade. Ciclosporina, uso terapêutico. Imunossupressores. Transplante de coração.

\footnotetext{
Work performed in Dante Pazzanese de Cardiology Institute, São Paulo, SP, Brazil.

1 - Dante Pazzanese de Cardiology Institute

2 - Messejana Hospital, Fortaleza, CE, Brazil

Correspondence address: Dr. Ricardo Manrique.

Av. Dr. Dante Pazzanese, 500.

São Paulo, SP. CEP 04012-180

Phone: (11) 5085-4095. Fax: (11) 3889-8248

E-mail: manriquericardo@aol.com
} 


\section{INTRODUCTION}

The production of generic medicines is a worldwide health policy which aims at reducing the costs of drugs without affecting their quality $[1,2]$

Several studies demonstrated that there are no differences in the bioavailability between generic

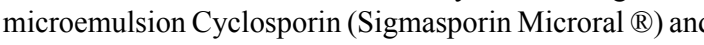
reference Cyclosporin (Sandimmun Neoral ${ }^{\circledR}$ ) [3-8]. In a previous study we discovered that there are no significan differences in relation to the side effects [3]. The las questions to be defined are the quality of the immunosuppression effects (therapeutic efficacy) and the risk of side effects (biosafety) in transplanted patients.

The concept of prescriptibility is a primarily qualifiable and not comparative. No graduation exists. It is possible or not to prescribe a drug.

This study aims to determine if the quality of results sanctions the prescription of the product in tests. The conditions to be satisfied are the clinical efficacy and biosafety.

As parameters of the therapeutic efficacy we used myocardial biopsy, cyclosporin blood levels, rejection rate, survival rate and functional class of the patients. All these parameters are analyzed and discussed in this work. If the results are satisfactory, the efficacy is guaranteed.

Biosafety analyzes the incidence and intensity of the side effects, principally focusing on those induced by the drug under research. This evaluation is generally laboratorial as their alterations precede the appearance of propedeutics. In our field, the most frequent undesired effect of cyclosporin is nephrotoxicity. To avoid this, special attention was paid to renal function. Also examinations were performed to control possible hepatic, biochemical and hematological alterations induced by the immunosuppression. Special importance was given to objective information, such as clinical cardiology data with support of the relevan examinations such as echocardiography and electrocardiography.

\section{Objective}

This study investigated the question of prescritability of generic microemulsion Cyclosporin (Sigmasporin Microral $\left.{ }^{\circledR}\right)$. Prescriptability is a term invented by BENNETT \& OLYAEI [1], who defined it as the possibility of the utilization of a medicine from the start of therapy. It is understood that to adopt a prescription, the medicine should demonstrate therapeutic power, as well as a low incidence and intensity of side effects. The term prescritability involves the concepts of therapeutic efficacy and of biosafety of the product being tested.

\section{METHODS}

\section{Protocol}

This is an open label study, in which heart transplant patients were treated with microemulsion A cyclosporin (genetic microemulsion cyclosporin or Sigmasporin Microral $\left.{ }^{\circledR}\right)$ in a triple arm trial, associated with corticoids and micophenolate mofetil. The dose of cyclosporin prescribed was 4.0 to $4.5 \mathrm{mg} / \mathrm{kg}$; the same used with Sandimmun Neoral ${ }^{\circledR}$.

The utilization of Sandimmun Neoral ${ }^{\circledR}$ as a generic medicine in Brazil has been authorized by the Government Health Authorities. This simplified the bureaucratic aspects of our study.

\section{Casuistic}

Consecutive over-18-year-old patients of both genders who had recently been submitted to heart transplantation operations and utilized generic microemulsion cyclosporin since the start of immunosuppression and for at least three months were included in this investigation. There were no exclusion criteria. These conditions were thus defined to eliminate any possibility of choosing cases with better prognoses which might cause bias in the results.

\section{Procedure}

The post-transplant evaluation anticipates frequent endomyocardial biopsies in the first six months after transplantation. It is necessary to remember that endomyocardial biopsy is the gold standard for the diagnosis and histological confirmation of rejection.

Determination of cyclosporinemia is routine. Our laboratory is specialized in the determination of the levels of cyclosporin in total blood, with publications of our own methods, especially in the area of micro-determination utilizing blood transported on filter paper, which was the object of several publications [9-11]. Measurement in total blood employed the process of competition between the cyclosporin in the blood of the patient and cyclosporin marked with the glucose-6-phosphate dehydrogenase enzyme for the binding site of the monoclonal antibody, with transformation of the nicotinamide adenine dinucleotide (NAD) to hydrogenated nicotinamide adenine dinucleotide (HNAD). This process results in a change of the kinetic absorption which can be spectrophotometrically measured.

To complete this evaluation we made an analysis of the pre-rejection lymphocytic morphological variations, cytoimmune monitoring, as well as early diagnosis of bacteremia and infectious processes by means of cyto-bacterial monitoring [12,13].

Also, side effects were assessed by routine biochemical and hematological methodologies. Clinical follow up was 
rigorous and frequent in the first six post-operative months after transplantation with electrocardiographic and echocardiographic evaluations.

\section{Immunosuppressant Protocol}

The utilization of cyclosporin in our immunosuppression regime is initiated on the second or third post-operative day, always when the serum creatinine level is within the normal range. The doses of cyclosporin are generally started at $1.5 \mathrm{mg} / \mathrm{kg}$ and are progressively increased until a full dose of 4 to $4.5 \mathrm{mg} / \mathrm{kg}$ on the $5^{\text {th }}$ or $6^{\text {th }}$ post-operative day [14]. This procedure aims to preserve the renal function, avoiding the association of high doses of cyclosporin with renal aggression caused by the cardiopulmonary bypass. The delay and the progressively increased dose of cyclosporin do not increase the incidence of acute rejection. In fact, the acute rejection rate in our series is very low. The cases of acute rejections are clearly related with pre-morbid circumstances which characterize a high immunity risk such as multiple-pregnancy recipients or donors, patients previously submitted to heart operations and multiple transfused patients.

The synchrony with other immunosuppressant drugs is also an important concern. Our protocol expects the use of elevated doses of corticoids during the first seven days of the post-operative period and, when the full dose of cyclosporin is reached the amount of corticoids is gradually reduced. The first measurement of cyclosporin in total blood is performed after reaching the full dose and repeated after seven days.

From the second post-operative day we start using micophenolate mofetil. Early use is possible because of its low toxicity and negligible incidence of undesirable effects, particularly at the levels recommended by us ( $500 \mathrm{mg}$ daily).

Our immunosuppression control protocol includes weekly biopsies in the first month, two-weekly in the second and third months and monthly biopsies from the fourth to sixth months. This gives a total of 11 endocardial biopsies per patient in the first six post-operative months. The number of biopsies was reduced in the absence of rejection in our patients to minimize the aggression in the post-operative period in cases that developed without complications.

The evaluation of the biopsies was made by an independent team from the immunosuppression sector of the pathologic anatomy department. Classification followed the system described by Dr Margaret BILLINGHAM of Stanford University - Palo Alto, California, USA [15].

\section{RESULTS}

Twenty patients with a mean age of $49.6 \pm 10.6$ years and average body weight of $62.4 \pm 10.3 \mathrm{~kg}$ participated in the study. In this cohort, 7 patients suffered from ischemic myocardiopathy and 13 from dilated heart disease. Four patients had a chagasic etiology.

The average post-operative follow-up time of our patients was 320 days. The first patient of the study has 16 months of follow up (Table 1).

Table 1 - Period of observation

\begin{tabular}{ll}
\hline Evolution & \\
\hline Mean & 10 months 17 days \\
Maximum & 16 months \\
Minimum & 03 months \\
\hline
\end{tabular}

In this period 151 biopsies were evaluated, where $31.7 \%$ were classified as group $0,43.7 \%$ group IA, $23.1 \%$ group IB, one sample was considered as group II $(0.6 \%)$ and one IIIA $(0.6 \%)$. This latter patient was a coronary patient who underwent multiple transfusions for previous coronary artery bypass grafting and who received pulse therapy with corticoids with clinical and histological regression. The results of the biopsies in this period are shown in Table 2 .

Table 2. Endomyocardial biopsies.

\begin{tabular}{llllllll}
\hline Degree & 0 & Ia & Ib & II & IIIa & IIIb & IV \\
\hline 48 & 66 & 25 & 1 & 1 & 0 & 0 \\
$31,7 \%$ & $43,7 \%$ & $23,1 \%$ & $0,6 \%$ & $0,6 \%$ & & \\
\hline
\end{tabular}

$\mathrm{N}^{\mathrm{o}}$ Patients $=20 ; \mathrm{N}^{\circ}$ Samples $=151$

The cyclosporin levels in total blood for the first postoperative year varied from 250 to $350 \mathrm{ng} / \mathrm{mL}$. All our patients presented levels within this range with an acceptable standard deviation (Table 3 ).

Table 3. Cyclosporinemia.

\begin{tabular}{ll}
\hline Cyclosporinemia & \\
\hline Mean & $303.9 \mathrm{ng} / \mathrm{mL}$ \\
Standard deviation & 61.7 \\
Maximum & 360 \\
Minimum & 193 \\
\hline
\end{tabular}

$\mathrm{N}^{\circ}$ Patients $=20 ; \mathrm{N}^{\circ}$ Examinations $=40$ last measurements

Our protocol considered the periodic evaluation of cyclosporinemia to be important. The ideal range of 
cyclosporinemia is related to the time interval between the transplantation and the dosage. Thus, as the evolution period increases, the ideal range reduces.

First year:

Second and third years:

Fourth and fifth years:

After the fifth year:

$$
\begin{aligned}
& 250-350 * \mathrm{ng} / \mathrm{mL} \\
& 200-300 \mathrm{ng} / \mathrm{mL} \\
& 100-200 \mathrm{ng} / \mathrm{mL} \\
& 100-150 \mathrm{ng} / \mathrm{mL}
\end{aligned}
$$

* With the use of micophenolate mofetil

Variation of the ideal range cyclosporinemia (12 hours after the last dose).

The aim of the reduction of the values is to diminish the risk of neoplasty associated to immunosuppression, as well as parenchymal fibrosis and nephrotoxicity. We stress the fact that these results were obtained with the use of micophenolate mofetil at low doses, achieving immunosuppression without increasing the risk of infection.

The hematological evolution was very favorable. The mean hemoglobin level was $12.8 \mathrm{~g} / \mathrm{dL}$, with a hematocrit level of $38.8 \%$, 8900 leukocytes and 264,000 platelets $/ \mathrm{mm}^{3}$ (Table 4 )

Table 4. Hematological control

\begin{tabular}{lllll}
\hline Examination & Hemoglobin & Hematocrit & Leukocytes & Platelets \\
\hline Mean & $12,8 \mathrm{gr} / \mathrm{dl}$ & $38,8 \%$ & $8900 \mathrm{~mm}^{3}$ & $264,000 \mathrm{~mm}^{3}$ \\
S.D. & 0,9 & 1,9 & 1920 & 63.320 \\
Maximum & 14,4 & 44 & 13200 & 458.000 \\
Minimum & 11,0 & 35 & 6300 & 158.000 \\
\hline
\end{tabular}

Mean of the last examinations; $\mathrm{N}=20$. S.D. - Standard Deviation

These results are very different to those from the time when azatioprine was used, which induced post-transplant iatrogenic leukopenia and platletopenia. We believe that the incorporation of micophenolate mofetil is responsible for this change. This drug eliminates the medullary toxic effect of azatioprine.

The results of the control of the renal function are demonstrated in table 5 .

Table 5. Biochemical controls.

\begin{tabular}{lll}
\hline Examination & Fasting glycemia & Creatinine \\
\hline Mean & $88,7 \mathrm{mg} / \mathrm{dL}$ & $1,3 \mathrm{mg} / \mathrm{d} / \mathrm{L}$ \\
Standard Deviation & $+/-9,0$ & $+/-0,2$ \\
Maximum & 110 & 1,8 \\
Minimum & 79 & 0,9 \\
\hline
\end{tabular}

Evolution of the glycemia and creatinine blood levels in the postoperative period. $\mathrm{N}^{\mathrm{o}}$ Patients $=20 ; \mathrm{N}^{\circ}$ examinations $=198$
The values of creatinine after transplantation normalized in all the patients who participated in this study and no case of severe renal dysfunction requiring intervention of a nephrologist was observed.

We did not confirm clinical or laboratorial hepatopathy in this group of patients.

Glycemia was maintained, on average, within the normal levels $(88.7 \pm 9.0 \mathrm{mg} / \mathrm{dL})$, even though one patient was diabetic type II.

The following were treated as serious infectious complications: one case of mediastinitis, in a patient with multiple complementary operations for homeostatic revision and for bleeding during surgery, which, without doubt explained this severe infection. This patient was released from hospital only to be readmitted because of deterioration in his state. A tomography confirmed a retrosternal collection, which was surgically managed and treated with antibiotics for three weeks, after which the patient was released from hospital again. A diabetic patient had a relapse of prostatitis, which was also resolved by antibiotic therapy. There were four cases of each of the following, transitory trembling, cephalea and gingival hyperplasia.

As a consequence of this evolution, the functional class of the 20 patients is grade I according to the NYHA.

\section{DISCUSSION}

Bioequivalence does not guarantee therapeutic equivalence, because, as was pointed out by BENET \& GOYAN [16], a great part of the studies on bioequivalence are performed in healthy volunteers and these data are then transferred to patients, without constituting evidence on the therapeutic efficacy and efficiency. In this study the authors propose two complementary concepts for bioequivalence: those of prescriptability and convertibility.

A drug can be prescribed when it demonstrates bioavailability, therapeutic efficacy and biosafety, within the standards demanded by the competent health authorities. Typically, prescriptability is applied to patients who initiate immunosuppression therapy using a drug test [17].

Convertibility, according to BENET [17] is the change of medicine using a drug test, in the same dose and the same via as the reference drug, without provoking alterations in the blood levels or modifications in the therapeutic effect or the presence of side effects. This qualification is reached when a minimally acceptable comparative bioequivalence is observed, in a cross-reference drug test. Thus, the patients are treated for a period with a drug, which is soon after exchanged for a second drug for an identical period. The comparative analysis should demonstrate compatible pharmacological evaluations within the limits of variability set by the public health control agency. Pharmacological 
studies are periodically complemented by clinical and laboratorial examinations to confirm the results. This type of evaluation has already been performed by our team in transplantation patients, demonstrating the convertibility of these products [3].

In our opinion these criticisms are pertinent, as pharmacological determinations are related to levels of drugs in the blood stream. However, we know that many drugs have an effect by their binding to cellular receptors, or directly by their cytoplasmatic concentration, circumstances which are not assessed in pharmacological examinations, but which are obvious in clinical comparisons of the efficacy and comparison of the incidence of side effects.

Even though, since the amendment by Waxman-Hatch in 1984 validated the concept of the possibility of eliminating clinical studies in humans and animals to verify the effect of generic drugs [18], we consider it ethical to perform a study of prescriptability of generic cyclosporin A microemulsion.

Our study is based on the clinical evaluation of the drug in transplantation patients. The set of information that we used in the standard evaluation of our patients permits a precise analysis of the therapeutic efficacy, as well as the side effects of immunosuppressant drugs.

Our experiment with heart transplantation patients treated exclusively with generic microemulsion cyclosporin (or Sigmasporin Microral®) with more than three months of evolution and the follow up of the patients. The mean age was $49.6 \pm 10.6$ years and the mean body weight was $62.4 \pm$ $10.3 \mathrm{~kg}$. In this group 7 patients suffered from ischemic heart disease and 13 from dilated cardiopathy, with 4 patients with an etiology of Chagas disease.

The mean clinical follow up was 10 months and 17 days, with a maximum of 16 months. In this period 151 biopsies were assessed, with $31.7 \%$ classified as group $0,43.7 \%$ classified as group IA and $23.1 \%$ in group IB, one sample was considered as group II $(0.6 \%)$ and one IIIA $(0.6 \%)$. This latter patient received pulse therapy with corticoids and the control biopsy on the third day after pulse therapy was IB. This patient today, after 7 months of evolution, is clinically controlled, and the biopsy is between IA and 0 , without the necessity of new rescue therapy. Such results are similar to those obtained with the reference drug.

The blood levels correspond to the dose administered and are equivalent to those obtained with Sandimmun Neoral ${ }^{\circledR}$. The mean cyclosporinemia (of the last 40 determinations) was $303.9 \pm 61.7 \mathrm{ng} / \mathrm{mL}$, within the range proposed in our regimen of immunosuppression.

Lymphocytic morphologic alterations compatible with evolution to rejection were not observed and in our clinical controls no signs of rejection or toxicity were registered, except for the patient with acute rejection. The biochemical and hematological laboratorial results were within the ranges of patients under immunosuppression, without severe nephrotoxic or hepatotoxic complications.

Special attention was paid to renal function. The levels of urea and creatinine in the pre-operative period were high in $90 \%$ of the patients (18 of 20 ), that is, pre-renal uremia, because of the lack of filtration pressure due to the heart failure. In all the patients there was a normalization of the urea and creatinine levels in the immediate post-operative period. In this cohort and until now, we did not observe any severe deterioration of the renal function. However, we are aware that it is a very short period of evolution for this type of complication. Table 4 shows the means and standard deviation of the serum creatinine.

Infectious states: one case with mediastinitis was registered, in one patient with multiple complementary operations for homeostatic revision, which without doubt explained this severe infectious state. This patient was released from hospital only to be readmitted because of deterioration. A tomography confirmed a retrosternal collection, which was managed surgically and treated with antibiotics for three weeks, after which the patient was released from hospital cured. A diabetic patient relapsed with prostatitis, which was also resolved by antibiotic therapy. Finally another patient suffered from genital herpes which satisfactorily responded to aciclovir.

As side effects, patients reported trembling at the start of treatment with cyclosporin that, with continuous use, disappeared, two patients reported myalgia which was also temporary and which ceased spontaneously and one case of nevritis was reported which required the use of B12 and other cases with gingival hyperplasia.

\section{CONCLUSIONS}

Generic microemulsion cyclosporin or Sigmasporin Microral ${ }^{\circledR}$ utilized at the same dosage gives excellent clinical results, demonstrating clinical efficacy and without registration of severe side effects. This study, with longterm immunosuppressant treatment with generic microemulsion cyclosporin or Sigmasporin Microoral®, confirms that these drugs are prescribable, without risk of loss of therapeutic efficacy or an increase of toxicity.

\section{BIBLIOGRAPHIC REFERENCES}

1. Bennett WM, Olyaei AJ. Pharmacoeconomics of immunosuppressive agents in renal transplant recipients. Transplant Proc 1999; 31(Suppl 3 A): 6S 
2. Christians U. Generic Immunosuppressants: the European perspective. Transplant Proc 1999;31 (Suppl 3 A):19S-22S.

3. Manrique R, Magalhães H, Dinkhuysen J, Correia E, LinWang HT, da Silva MA et al.. Comparação farmacocinética entre apresentações de Ciclosporina A em microemulsão em transplantados cardíacos. J Bras Nefrol 2002; 24:26-32.

4. Sinescu I, Lopes HV, Foschi D, Jen LH, Oliani C. New cyclosporine microemulsion randomized, cross-ove bioequivalence steady-state study in renal transplanted patients. Eur Rev Med Pharmacol Sci 1999:3:11-8.

5. Tanasescu C, Serbanescu A, Spadaro A, Jen LH, Oliani C. Comparison of two microemulsion of cyclosporine $A$ in healthy volunteers. Eur Rev Med Pharmacol Sci 1999;3:5-9.

6. Spadaro A, Ferreira AF, Tanascescu C, Serbanescu A, Lope HV. Comparação de duas preparações de ciclosporina A em microemulsão em voluntários sadios. Rev Bras Med 1999;56:1058-61.

7. Foschi D, Ferreira AF, Oliani C, Sinescu I, Lopes HV. Estudo de bioequivalência, aleatório e cruzado, no estado de equilíbrio, de uma ciclosporina similar em microemulsão em transplantados renais. Rev Bras Med 1999;56:1062-7.

8. De Nucci G. Resumo do Estudo GDN-15/00, intitulado Cyclosporine Bioequivalence Study.

9. Manrique RV, Lin HT. Optimization of the blood sample filter paper technique for cyclosporine determination. Transplant Proc 1990; 22:1231-3.
10. Lin-Wang HT, Manrique R. Dosagem de ciclosporina em amostras transportadas de sangue absorvido em papel de filtro. Laes \& Haes 1999; 118:120-32.

11. Lin HT. Aplicação da técnica de imunoensaio enzimático de multiplicação para dosagem de ciclosporina em amostra de sangue absorvido no papel. [Monografia]. São Paulo: Instituto "Dante absorvido no papel. [Monografia]. São Paulo: Instituto "Dante
Pazzanese" de Cardiologia. Curso de Especialização em Metodologia da Pesquisa Experimental em Ciências da Saúde, 2000.

12. Manrique R, Carvalho EC. Imunocitomonitorização em pacientes transplantados cardíacos. Rev Bras Cir Cardiovascular 1990; 5:54-60.

13. Carvalho EC. Técnica de citobactério-monitorização (CBM) [Monografia]. São Paulo: Instituto "Dante Pazzanese" de Cardiologia. Curso de Especialização em Metodologia da Pesquisa Experimental em Ciências da Saúde, 2000.

14. Manrique R. Terapia imunossupressora no transplante cardíaco. Rev Soc Cardiol Estado de São Paulo 1995;5: 643-54.

15. Billingham ME. Diagnosis of cardiac rejection by endomyocardial biopsy. J Heart Transplant 1982;1:25-30.

16. Benet LZ, Goyan JE. Bioequivalence and narrow therapeutic index drugs. Pharmacotherapy 1995;15:433-40.

17. Benet LZ. Understanding bioequivalence testing. Transplant Proc 1999; 31(Suppl 3 A): 7S-9S.

18. Dighe SV. A review of the safety of generic drugs. Transplant Proc 1999; 31(Suppl 3 A): 23S-4S. 